\title{
Effect of metabolizable protein intake on rates of plasma leucine turnover and protein synthesis in heifers
}

\author{
H. SANO ${ }^{1 *}$, M. KAJITA ${ }^{1}$, M. ITO ${ }^{1}$, T. FUJITA ${ }^{1}$ AND A. TAKAHASHI ${ }^{2}$ \\ ${ }^{1}$ Faculty of Agriculture, Iwate University, Morioka 020-8550, Japan \\ ${ }^{2}$ College of Agriculture, Akita Prefectural University, Ohgata 010-0444, Japan
}

(Revised MS received 29 August 2007; First published online 16 November 2007)

\begin{abstract}
SUMMARY
An isotope dilution method using $\left[1-{ }^{13} \mathrm{C}\right]$ leucine (Leu) infusion together with open-circuit calorimetry was applied to determine the effect of metabolizable protein (MP) intake on rates of plasma Leu turnover and whole body protein synthesis (WBPS) in six heifers. WBPS rate was estimated from rate of plasma Leu turnover and Leu oxidation to carbon dioxide. The experiment consisted of three levels of MP intake and was conducted in a two $3 \times 3$ Latin square designs of three 21-day periods. The experimental diet consisted of mixed hay, maize and soybean meal. Dietary MP intake of each dietary treatment was $4 \cdot 3,4.5$ and $4.9 \mathrm{~g} / \mathrm{kg} \mathrm{BW}^{0.75} /$ day by changing maize and soybean meal weights. Metabolizable energy (ME) intake was similar for all dietary treatments. When plasma $\alpha-\left[1-{ }^{13} \mathrm{C}\right]$ keto-isocaproic acid enrichments were used as markers indicating intracellular Leu enrichments, plasma Leu turnover rate (LeuTR) increased $(P=0.012)$ and WBPS tended to increase $(P=0.091)$ as MP intake increased. In contrast, plasma LeuTR and WBPS were not influenced if plasma $\left[1-{ }^{13} \mathrm{C}\right]$ Leu was taken to indicate intracellular Leu enrichments. Total and plasma Leu oxidation rates did not change but intracellular Leu oxidation increased $(P=0.044)$ with increasing MP intake. In heifers, it is suggested that rates of plasma Leu turnover and WBPS are influenced by dietary MP intake, independent of ME intake, although the change in MP intake was relatively small.
\end{abstract}

\section{INTRODUCTION}

Amino acids, supplied by absorption from digestive tracts and by degradation from tissue protein, are utilized via a variety of metabolic routes. Leucine (Leu) is, however, either used for protein synthesis or oxidized to carbon dioxide $\left(\mathrm{CO}_{2}\right)$ via $\alpha$-ketoisocaproic acid ( $\alpha$-KIC) (Cobelli et al. 1991). Therefore, the isotope dilution method of labelled Leu is widely applied for estimation of whole body protein synthesis (WBPS).

Dietary intake influenced plasma Leu turnover rate (LeuTR) and WBPS in growing cows (Hammond et al. 1987; Dawson et al. 1998; Lapierre et al. 1999). Sano et al. (2004) studied the effect of dietary protein intake on WBPS and whole body protein degradation using the $\left[1-{ }^{13} \mathrm{C}\right]$ Leu method and $\mathrm{N}$ balance test in sheep and reported that high protein intake had little

\footnotetext{
* To whom all correspondence should be addressed. Email: sano@iwate-u.ac.jp
}

effect on plasma LeuTR and WBPS, and enhanced protein deposition with reduced whole body protein degradation rather than increased WBPS. Supply of metabolizable protein (MP), consisting of digestible microbial true protein and digestible undegraded feed protein (AFRC 1993), influenced absorption of essential amino acids, plasma LeuTR and WBPS in lactating cows (Lapierre et al. 2002; Raggio et al. 2004). Therefore, it was hypothesized that WBPS was affected by dietary MP intake even when metabolizable energy (ME) intake was constant. However, in heifers, less information is available about the effect of MP intake in isoenergetic diets on plasma LeuTR and WBPS. In the present experiment, therefore, plasma LeuTR and WBPS were determined by the $\left[1-{ }^{13} \mathrm{C}\right]$ Leu method in heifers fed isoenergetic diets estimated to contain three levels of MP. Moreover, plasma and intracellular Leu oxidation rates were separately calculated from both enrichments of plasma $\left[1-{ }^{13} \mathrm{C}\right]$ Leu and $\alpha-\left[1-{ }^{13} \mathrm{C}\right] \mathrm{KIC}$ as described by Wolfe et al. (1982). 
Table 1. Composition of the dietary treatments

\begin{tabular}{|c|c|c|c|}
\hline & \multicolumn{3}{|c|}{ Treatment } \\
\hline & Lo-MP & Me-MP & Hi-MP \\
\hline $\begin{array}{l}\text { Mixed hay } \\
\left(\mathrm{g} / \mathrm{kg} \mathrm{BW}^{0.75} / \text { day }\right)\end{array}$ & $36 \cdot 7$ & $36 \cdot 7$ & $36 \cdot 7$ \\
\hline $\begin{array}{l}\text { Maize } \\
(\mathrm{g} / \mathrm{kg} \mathrm{BW} \\
0.75 / \text { day })\end{array}$ & $17 \cdot 0$ & $12 \cdot 1$ & $5 \cdot 2$ \\
\hline $\begin{array}{l}\text { Soybean meal } \\
\left(\mathrm{g} / \mathrm{kg} \mathrm{BW}^{0.75} / \text { day }\right)\end{array}$ & $1 \cdot 3$ & $6 \cdot 3$ & $14 \cdot 0$ \\
\hline $\begin{array}{l}\text { CP } \\
\left(\mathrm{g} / \mathrm{kg} \mathrm{BW}^{0.75} / \text { day }\right)\end{array}$ & $6 \cdot 0$ & $7 \cdot 8$ & $10 \cdot 5$ \\
\hline $\begin{array}{l}\mathrm{MP}^{*} \\
\left(\mathrm{~g} / \mathrm{kg} \mathrm{BW} \mathbf{B}^{0.75} / \text { day }\right)\end{array}$ & $4 \cdot 3$ & $4 \cdot 5$ & 4 \\
\hline $\begin{array}{l}\mathrm{ME}^{*} \\
\left(\mathrm{~kJ} / \mathrm{kg} \mathrm{BW} \mathbf{0}^{0.75} / \text { day }\right)\end{array}$ & 590 & 588 & 596 \\
\hline
\end{tabular}

* Assumed from AFRC (1993).

\section{MATERIALS AND METHODS}

\section{Animals and diets}

Six non-pregnant, non-lactating Holstein heifers, aged $18 \pm 2$ months and weighing $521 \pm 37 \mathrm{~kg}$ were used. They were assigned to a two $3 \times 3$ Latin square design for 21 days each. The experimental diet consisted of mixed hay of Kentucky bluegrass and Reed canarygrass (3:7; ME 9.2 MJ/kg, $111 \mathrm{~g}$ crude protein (CP) $/ \mathrm{kg}$ air dry matter), maize (ME $13.8 \mathrm{MJ} / \mathrm{kg}, 82 \mathrm{~g}$ $\mathrm{CP} / \mathrm{kg}$ air dry matter) and soybean meal (ME $13.3 \mathrm{MJ} / \mathrm{kg}, 427 \mathrm{~g} \mathrm{CP} / \mathrm{kg}$ air dry matter). The dietary treatments consisted of three levels of MP intake low MP (Lo-MP), medium MP (Me-MP) and high MP (Hi-MP), respectively, as estimated by the Agricultural and Food Research Council (AFRC 1993) and the experimental diets were prepared with changing maize and soybean meal weights (Table 1). ME intake was similar for all treatments (AFRC 1993). CP intake increased with increasing MP intake. The heifers were housed in a stanchion stall in the dairy barn and were fed the mixed hay at 08.30 and $15.30 \mathrm{~h}$ and maize and soybean meal at 13.30 and $16.30 \mathrm{~h}$. They were allowed to move outside the house and to rest in a clay field with partial shade after the morning feed. Water was available ad libitum. Two catheters for infusion and blood sampling were inserted into both jugular veins on the 20th day and were filled with a sterile solution of $38 \mathrm{~g}$ trisodium citrate $/ 1$.

\section{Experimental procedures}

Combined experiments using open-circuit calorimetry and the isotope dilution procedure for determination of plasma Leu and protein metabolism were carried out in the stanchion stall on the 21st day of each dietary treatment. On the experimental day, the heifers were fitted with a clear head chamber (approximately $1 \mathrm{~m}^{3}$ ) for collecting gaseous samples throughout the samplings and were fed the morning diet but were not fed during the $\left[1-{ }^{13} \mathrm{C}\right]$ Leu infusion. The heifers could freely access an automated waterer in the head chamber. At $09.00 \mathrm{~h}, 10 \mu \mathrm{mol} / \mathrm{kg} \mathrm{BW}^{\mathbf{0 . 7 5}}$ of $\left[1-{ }^{13} \mathrm{C}\right]$ Leu (L-leucine- $1-{ }^{13} \mathrm{C}, 99$ atom $\%{ }^{13} \mathrm{C}$; Isotec Inc., A. Matheson, USA) and $3 \mu \mathrm{mol} / \mathrm{kg} \mathrm{BW} \mathbf{B W}^{\mathbf{0} 75}$ of $\left[{ }^{13} \mathrm{C}\right]$ sodium bicarbonate (sodium bicarbonate $-{ }^{13} \mathrm{C}$, 99.2 atom $\%{ }^{13} \mathrm{C}$; Isotec Inc., A Matheson, USA) dissolved in saline solution ( $9 \mathrm{~g}$ sodium chloride/l) was injected into the infusion catheter as a priming dose. $\left[1-{ }^{13} \mathrm{C}\right]$ Leucine was then continuously infused by a multichannel peristaltic pump (AC-2120, Atto Co. Ltd, Japan) at a rate of $10 \mu \mathrm{mol} / \mathrm{kg} \mathrm{BW}^{0.75} / \mathrm{h}$ through the same catheter for $8 \mathrm{~h}$. Blood samples $(10 \mathrm{ml})$ were taken from the sampling catheter immediately before (preinfusion background) and at 30 -min intervals during the last $2 \mathrm{~h}$ of $\left[1-{ }^{13} \mathrm{C}\right]$ Leu infusion. Samples were transferred into centrifuge tubes containing heparin sodium and were in ice until centrifugation. Blood samples were centrifuged at $1500 \mathrm{~g}$ for $20 \mathrm{~min}$ at $4{ }^{\circ} \mathrm{C}$, and the plasma was stored at $-25^{\circ} \mathrm{C}$ until analyses. For determination of gaseous metabolism, oxygen $\left(\mathrm{O}_{2}\right)$ consumption and $\mathrm{CO}_{2}$ production of the heifer were analysed by an open-circuit system throughout the experiment. An aliquot of the exhaled gas was collected into $4 \mathrm{ml}$ of $1 \mathrm{~N} \mathrm{NaOH}$ to determine ${ }^{13} \mathrm{CO}_{2}$ enrichments for $30 \mathrm{~min}$ before (preinfusion background) and at 6 , $6 \cdot 5,7$ and $7 \cdot 5 \mathrm{~h}$ of $\left[1-{ }^{13} \mathrm{C}\right] \mathrm{Leu}$ infusion and the $\mathrm{NaOH}$ solution was stored at $-25{ }^{\circ} \mathrm{C}$ until analysis of ${ }^{13} \mathrm{CO}_{2}$ enrichments. After completing determination of gaseous metabolism, the catheters were removed and the heifer was fed the diet. The management and experiment corresponded to the guidelines established by the Animal Care Committee of Iwate University. The experiment was performed without noticeable stress to the heifers.

\section{Analyses}

Derivatization of plasma amino acids and $\alpha$-keto acids was performed by the procedures of Rocchiccioli et al. (1981) and Calder \& Smith (1988) with slight modifications as described previously (Sano et al. 2004). The isotope abundance of plasma $\left[1-{ }^{13} \mathrm{C}\right] \mathrm{Leu}$ and $\alpha-\left[1-{ }^{13} \mathrm{C}\right] \mathrm{KIC}$ derivatives was determined by gas chromatography mass spectrometry (QP-2010, Shimadzu, Japan) with selected ion monitoring. Nleucine and $\alpha$-ketovaleric acid were used as external standards for determination of plasma Leu and $\alpha$ KIC concentrations, respectively. To determine the isotope abundance of ${ }^{13} \mathrm{CO}_{2}, 1 \mathrm{ml}$ of the $\mathrm{NaOH}$ solution fixed with exhaled $\mathrm{CO}_{2}$ was taken in a $3 \mathrm{ml}$ vial which was capped with rubber. After the vial was 
vacuumed, the $\mathrm{NaOH}$ solution was acidified by injecting $2 \mathrm{ml}$ of $6 \mathrm{~N} \mathrm{H}_{2} \mathrm{SO}_{4}$ using a syringe, and a part of liberated $\mathrm{CO}_{2}$ was taken by the microsyringe and ${ }^{13} \mathrm{CO}_{2}$ enrichments of liberated $\mathrm{CO}_{2}$ were determined by gas chromatography/combustion/isotope ratio mass spectrometry $\left(\right.$ DELTA $^{\text {plus }}$, Thermo Electron Corp., USA). Oxygen consumption and $\mathrm{CO}_{2}$ production were continuously determined from inlet and outlet air with a respiratory gas analysis system (Metabolic Monitor, Coast Electronics, UK). Concentrations of plasma free amino acids, ammonia and urea at the preinfusion period were determined with an automated amino acid analyser (JLC-500/V, JEOL, Japan). Plasma insulin was determined by a radioimmunoassay kit (IRI 'Eiken', Eiken Chemical Co. Ltd, Japan). The intra- and inter-assay coefficient of variance accounted for were 6 and $9 \%$, respectively.

\section{Calculations}

Mean values with standard errors of the means (S.E.M.) are given. Rates of plasma LeuTR, total Leu oxidation (LeuOX), plasma Leu oxidation (LeuOXpl), intracellular Leu oxidation (LeuOXin) and fractional Leu oxidation (FLeuOX) were calculated using the equations by Goodenough et al. (1982) and Krishnamurti \& Janssens (1988).

$$
\text { LeuTR }=I \times[(1 / E)-1]
$$

where $I$ is the infusion rate of $\left[1-^{13} \mathrm{C}\right]$ Leu and $E$ is the plasma isotope enrichment of $\left[1-{ }^{13} \mathrm{C}\right]$ Leu or $\alpha-\left[1-{ }^{13} \mathrm{C}\right] \mathrm{KIC}$ during the steady-state conditions.

$$
\begin{aligned}
& \text { LeuOX }=E \mathrm{CO}_{2} / E \mathrm{KIC} / 0.81 \times V \mathrm{CO}_{2} \\
& \text { LeuOXpl }=E \mathrm{CO}_{2} / E \mathrm{LEU} / 0.81 \times V_{\mathrm{CO}_{2}} \\
& \text { LeuOXin }=\mathrm{LeuOX}-\mathrm{LeuOXpl} \\
& \text { FLeuOX }=\text { LeuOX } / \text { LeuTR }
\end{aligned}
$$

where EKIC and ELEU are the plasma isotope enrichments of $\alpha-\left[1-{ }^{13} \mathrm{C}\right] \mathrm{KIC}$ and $\left[1-{ }^{13} \mathrm{C}\right] \mathrm{Leu}$, respectively, $\mathrm{ECO}_{2}$ is the isotope enrichment of exhaled ${ }^{13} \mathrm{CO}_{2}$ and $\mathrm{VCO}_{2}$ is the $\mathrm{CO}_{2}$ production rate. The recovery fraction of the exhaled $\mathrm{CO}_{2}$ to $\mathrm{CO}_{2}$ produced in the animal body was assumed to be 0.81 (Allsop et al. 1978; Wolfe et al. 1982). WBPS was calculated from the following equation.

$$
\begin{aligned}
\text { WBPS }= & (\text { LeuTR }- \text { LeuOX }) / \text { Leu concentration } \\
& \text { in carcass protein }
\end{aligned}
$$

Leucine concentration in carcass protein was assumed to be $60 \mathrm{~g} / \mathrm{kg}$ (Lobley et al. 1980).

Heat production at 5.5 and $8 \mathrm{~h}$ after the initiation of the isotope dilution method was calculated from $\mathrm{O}_{2}$ consumption and $\mathrm{CO}_{2}$ production according to the

\begin{tabular}{|c|c|c|c|c|c|}
\hline \multirow[b]{2}{*}{$(\mu \mathrm{mol} / \mathrm{l})$} & \multicolumn{3}{|c|}{ Treatment } & \multirow[b]{2}{*}{ S.E.M.* } & \multirow[b]{2}{*}{$P$-value } \\
\hline & Lo-MP & Me-MP & Hi-MP & & \\
\hline No. of heifers & 6 & 6 & 6 & & \\
\hline Arg & 134 & 132 & 149 & $6 \cdot 6$ & 0.282 \\
\hline $\mathrm{His}$ & 77 & 77 & 80 & $2 \cdot 5$ & 0.702 \\
\hline Ile & 107 & 114 & 120 & $3 \cdot 9$ & 0.287 \\
\hline Leu & 142 & 152 & 159 & $4 \cdot 0$ & $0 \cdot 178$ \\
\hline Lys & 94 & 95 & 122 & $10 \cdot 3$ & $0 \cdot 343$ \\
\hline Met & 25 & 28 & 32 & $1 \cdot 4$ & 0.086 \\
\hline Phe & 53 & 54 & 53 & $1 \cdot 9$ & 0.955 \\
\hline Thr & 84 & 84 & 86 & $4 \cdot 6$ & 0.795 \\
\hline Val & 243 & 266 & 275 & $6 \cdot 2$ & $<0.01$ \\
\hline Ala & 234 & 225 & 236 & $9 \cdot 2$ & 0.371 \\
\hline Asp & 14 & 12 & 17 & $1 \cdot 3$ & 0.390 \\
\hline Glu & 100 & 94 & 128 & $6 \cdot 5$ & 0.034 \\
\hline Gly & 335 & 324 & 315 & $10 \cdot 9$ & 0.759 \\
\hline Pro & 79 & 112 & 132 & $9 \cdot 9$ & 0.068 \\
\hline Ser & 106 & 105 & 111 & $5 \cdot 2$ & 0.951 \\
\hline Asn & 32 & 29 & 34 & $1 \cdot 9$ & 0.507 \\
\hline Gln & 376 & 367 & 330 & $12 \cdot 3$ & $0 \cdot 271$ \\
\hline Tyr & 49 & 47 & 52 & $2 \cdot 2$ & $0 \cdot 196$ \\
\hline Ammonia & 182 & 174 & 222 & $12 \cdot 2$ & $0 \cdot 240$ \\
\hline $\begin{array}{l}\text { Urea } \\
(\mathrm{mmol} / \mathrm{l})\end{array}$ & $4 \cdot 4$ & $5 \cdot 8$ & 6.9 & 0.37 & 0.015 \\
\hline $\begin{array}{l}\text { Insulin } \\
(\mu \mathrm{U} / \mathrm{ml})\end{array}$ & $12 \cdot 7$ & $9 \cdot 9$ & $9 \cdot 9$ & 0.73 & $0 \cdot 066$ \\
\hline
\end{tabular}
Brouwer's equation (Brouwer 1965) excluding the correction for urinary $\mathrm{N}$ and methane production as described by Young et al. (1975).
Table 2. Effect of MP intake on plasma amino acid, ammonia, urea and insulin concentrations at the preinfusion period in heifers

* S.E.M. $=$ standard errors of the means.

\section{Statistical model}

Data were analysed with the MIXED procedure of the SAS (1996). The fixed effects in the model were period and diet. The random effect was heifers. Results were considered significant at the $P<0.05$ level. The tendency was defined as $0.05 \leqslant P<0 \cdot 10$. If the effect of diet was significant, the Tukey-Kramer adjustment was used and the significance was $P<0.05$.

\section{RESULTS}

Plasma valine and glutamic acid concentrations at preinfusion increased $(P<0.05)$ as MP intake increased, but other amino acids were not influenced by MP intake (Table 2). During the preinfusion period, plasma urea concentrations increased $(P=0 \cdot 015)$ but plasma ammonia concentrations remained unchanged $(P=0 \cdot 240)$ with increasing MP intake. Plasma insulin concentrations tended to decrease $(P=0 \cdot 066)$ with increasing MP intake.

Concentrations of plasma Leu and $\alpha$-KIC and enrichments of plasma $\left[1-{ }^{13} \mathrm{C}\right] \mathrm{Leu}$ and $\alpha-\left[1-{ }^{13} \mathrm{C}\right] \mathrm{KIC}$ and 
Table 3. Effect of MP intake on plasma concentrations of Leu and $\alpha-K I C$, rates of Leu turnover, Leu oxidation, WBPS and heat production in heifers

\begin{tabular}{|c|c|c|c|c|c|}
\hline & \multicolumn{3}{|c|}{ Treatment* } & \multirow[b]{2}{*}{ S.E.M. $\dagger$} & \multirow[b]{2}{*}{$P$-value } \\
\hline & Lo-MP & Me-MP & Hi-MP & & \\
\hline No. of heifers & 6 & 6 & 6 & - & \\
\hline \multicolumn{6}{|l|}{ Leu } \\
\hline Concentration $(\mu \mathrm{mol} / \mathrm{l})$ & 144 & 147 & 152 & $7 \cdot 8$ & $0 \cdot 470$ \\
\hline $\begin{array}{l}\text { Turnover rate } \\
\left(\mu \mathrm{mol} / \mathrm{kg} \mathrm{BW}^{0.75} / \mathrm{h}\right)\end{array}$ & 347 & 357 & 388 & $13 \cdot 4$ & 0.465 \\
\hline \multicolumn{6}{|l|}{$\alpha$-KIC } \\
\hline Concentration $(\mu \mathrm{mol} / \mathrm{l})$ & 65 & 67 & 63 & $4 \cdot 4$ & 0.795 \\
\hline $\begin{array}{l}\text { Turnover rate } \\
\left(\mu \mathrm{mol} / \mathrm{kg} \mathrm{BW}^{0.75} / \mathrm{h}\right)\end{array}$ & 480 & 511 & 566 & $17 \cdot 9$ & 0.012 \\
\hline \multicolumn{6}{|l|}{$\begin{array}{l}\text { Leu oxidation } \\
\left(\mu \mathrm{mol} / \mathrm{kg} \mathrm{BW}^{0.75} / \mathrm{h}\right)\end{array}$} \\
\hline Total & 99 & 117 & 140 & $7 \cdot 8$ & $0 \cdot 167$ \\
\hline plasma & 72 & 83 & 97 & 5.9 & 0.534 \\
\hline intracellular & 27 & 34 & 43 & $3 \cdot 0$ & 0.044 \\
\hline Fractional Leu oxidation rate & $0 \cdot 20$ & $0 \cdot 23$ & $0 \cdot 25$ & $0 \cdot 011$ & $0 \cdot 448$ \\
\hline \multicolumn{6}{|l|}{ Protein $\left(\mathrm{g} / \mathrm{kg} \mathrm{BW}^{0.75} /\right.$ day $)$} \\
\hline Intake & $6 \cdot 0$ & $7 \cdot 8$ & $10 \cdot 7$ & $0 \cdot 54$ & $<0.01$ \\
\hline Synthesis (Leu) & $14 \cdot 4$ & $14 \cdot 3$ & $15 \cdot 2$ & 0.49 & $0 \cdot 654$ \\
\hline Synthesis $(\alpha-\mathrm{KIC})$ & $19 \cdot 9$ & $20 \cdot 6$ & $22 \cdot 3$ & 0.69 & 0.091 \\
\hline $\begin{array}{l}\text { Heat production } \ddagger \\
\left(\mathrm{kJ} / \mathrm{kg} \mathrm{BW}^{0.75} / \mathrm{h}\right)\end{array}$ & $27 \cdot 8$ & $29 \cdot 0$ & $29 \cdot 5$ & 0.63 & $0 \cdot 410$ \\
\hline Respiratory quotient $\ddagger$ & $0 \cdot 80$ & $0 \cdot 80$ & 0.86 & 0.014 & $0 \cdot 175$ \\
\hline
\end{tabular}

* Mean values from 6 to $8 \mathrm{~h}$ of $\left[1{ }^{13} \mathrm{C}\right]$ Leu infusion.

$\dagger$ S.E.M. $=$ standard errors of the means.

$\ddagger$ Mean values at $5 \cdot 5$ and $8 \mathrm{~h}$ of $\left[1-{ }^{13} \mathrm{C}\right]$ Leu infusion.

exhaled ${ }^{13} \mathrm{CO}_{2}$ were virtually constant during the last $2 \mathrm{~h}$ for all of the isotope dilution method (data not shown). The $\%$ variance accounted for isotope enrichments during the period were $8 \cdot 1,7 \cdot 8$ and $12 \cdot 6$, respectively. Concentrations of plasma Leu and $\alpha$ KIC did not change with MP intake (Table 3 ). The enrichments obtained from plasma $\alpha-\left[1-{ }^{13} \mathrm{C}\right] \mathrm{KIC}$ $(0 \cdot 022 \pm 0.0008)$ were lower than those from plasma $\left[1-{ }^{13} \mathrm{C}\right]$ Leu $(0 \cdot 031 \pm 0 \cdot 0009)$, and the overall ratio was $0 \cdot 71 \pm 0 \cdot 018$. Therefore, plasma LeuTR calculated from plasma $\alpha-\left[1-{ }^{13} \mathrm{C}\right] \mathrm{KIC}$ enrichments was higher than that from plasma $\left[1-{ }^{13} \mathrm{C}\right] \mathrm{Leu}$ enrichments. Plasma LeuTR increased $(P=0.012)$ with increasing MP intake and was greater $(P<0.05)$ for the Hi-MP diet than for the Lo-MP diet, when plasma $\alpha$ $\left[1-{ }^{13} \mathrm{C}\right] \mathrm{KIC}$ enrichments were used. However, plasma LeuTR was not influenced by MP intake, when plasma $\left[1-{ }^{13} \mathrm{C}\right]$ Leu enrichments were used. Total Leu oxidation rate and LeuOXpl did not change $(P=$ 0.167 and $P=0.534$, respectively) but LeuOXin increased $(P=0.044)$ with increasing MP intake and was greater $(P<0.05)$ for the Hi-MP diet than for the
Lo-MP diet. Fractional Leu oxidation rate did not change $(P=0.448)$ with MP intake.

WBPS tended to increase $(P=0.091)$ with MP intake, when plasma $\alpha-\left[1-{ }^{13} \mathrm{C}\right] \mathrm{KIC}$ enrichments were used for a precursor. However, WBPS was not influenced $(P=0.654)$ by MP intake, when plasma $\left[1-{ }^{13} \mathrm{C}\right]$ Leu enrichments were used. Heat production and respiratory quotient were also not influenced ( $P=0.410$ and $P=0 \cdot 175$, respectively) by MP intake, but respiratory quotient for Hi-MP diet was numerically higher than the Lo-MP and Me-MP diets.

\section{DISCUSSION}

Of the isotopic tracer methods for whole body protein metabolism proposed, the isotope dilution method of $\left[1-{ }^{13} \mathrm{C}\right]$ Leu with open-circuit calorimetry is widely applied to cows and sheep as well as humans (Lobley 1992), because Leu is either utilized for protein synthesis or oxidized to $\mathrm{CO}_{2}$ via $\alpha$-KIC (Cobelli et al. 1991). Lapierre et al. (1999) studied the effect of feed intake level on protein metabolism using the 
$\left[1-{ }^{13} \mathrm{C}\right]$ Leu method in growing beef steers and determined both plasma $\left[1-{ }^{13} \mathrm{C}\right]$ Leu and $\alpha-\left[1{ }^{13} \mathrm{C}\right] \mathrm{KIC}$ enrichments for estimation of whole body LeuTR, but only plasma $\alpha-\left[1-{ }^{13} \mathrm{C}\right] \mathrm{KIC}$ enrichments were used for WBPS calculation. In another study, Lapierre et al. (2002) conducted the same experimental procedure in lactating cows, determined both enrichments of plasma $\left[1-{ }^{13} \mathrm{C}\right]$ Leu and $\alpha-\left[1-{ }^{13} \mathrm{C}\right] \mathrm{KIC}$ as precursors, and reported that LeuTR was 13-22\% higher plasma $\alpha-\left[1-{ }^{13} \mathrm{C}\right] \mathrm{KIC}$ enrichments than plasma $\left[1-{ }^{13} \mathrm{C}\right]$ Leu enrichments used for calculation. Matthews et al. (1980) suggested that plasma $\alpha-\left[1-{ }^{13} \mathrm{C}\right] \mathrm{KIC}$ enrichments should be used as an indicator of intracellular Leu metabolism. Therefore, the $\left[1{ }^{13} \mathrm{C}\right]$ Leu method was applied to heifers, either precursor for calculation of LeuTR and WBPS was determined, and the results obtained from enrichments of plasma $\alpha-\left[1-{ }^{13} \mathrm{C}\right] \mathrm{KIC}$ were discussed.

For application of the isotope dilution method, there are some arguments that the isotope infused influences nutrient utilization in the body (Anthony et al. 2000). In the present experiment, the infusion rate of $\left[1{ }^{13} \mathrm{C}\right]$ Leu employed was similar to that used in growing beef steers (Lapierre et al. 1999) and was lower than that in lactating cows (Lapierre et al. 2002). The pooled isotope enrichments of $\left[1-{ }^{13} \mathrm{C}\right] \mathrm{Leu}$ and $\alpha-\left[1-{ }^{13} \mathrm{C}\right] \mathrm{KIC}$ were similar to those reported in growing steers (Lapierre et al. 1999). Tessari et al. (1985) reported that in humans infusion of stable isotope up to approximately $0 \cdot 10$ of the Leu carbon flux did not have a significant effect on Leu metabolism. Because the infusion rate of $\left[1-{ }^{13} \mathrm{C}\right]$ Leu was approximately $0.02-0.03$ of plasma LeuTR, the isotope infused would not influence plasma LeuTR. Plasma LeuTR was comparable with those reported in growing cows (Hammond et al. 1987; Dawson et al. 1998; Lapierre et al. 1999).

Lobley et al. (1987) studied the effect of progressive reduction in food intake on WBPS with the $\left[1-{ }^{14} \mathrm{C}\right]$ Leu method in finishing beef steers and found that food intake influenced overall protein metabolism. Dawson et al. (1998) studied plasma LeuTR in crossbred young steers fed six intake levels, and observed that plasma LeuTR increased with increased dietary intake. It was expected that both dietary energy and $\mathrm{N}$ intake influenced WBPS, because the rate of microbial protein synthesis given adequate $\mathrm{N}$ intake is believed to be proportional to energy intake (Nolan 1993; Obara et al. 1994). Fujita et al. (2006) applied a $\left[{ }^{2} \mathrm{H}_{5}\right]$ phenylalanine model to determine the effect of non-protein energy intake on protein metabolism in goats and reported that WBPS was enhanced with increasing dietary energy intake even when dietary $\mathrm{CP}$ intake was constant, suggesting that microbial protein, a part of MP, influences WBPS. The present experiment demonstrated that, in heifers, plasma LeuTR increased and WBPS tended to increase with increased MP intake, when enrichments of plasma $\alpha-\left[1-{ }^{13} \mathrm{C}\right] \mathrm{KIC}$ were used. Lapierre et al. (2002) reported that in lactating cows producing $16 \mathrm{~kg}$ milk/day increased MP supply (1654 and $1930 \mathrm{~g}$ /day) enhanced Leu absorption and LeuTR, even though $\mathrm{N}$ intake was similar. Although the increment of MP intake in the present experiment $(1: 1 \cdot 05: 1 \cdot 14)$ was slightly less than that $(1: 1 \cdot 17)$ in lactating cows (Lapierre et al. 2002) and ME intake was similar between diets, a significant increase in plasma LeuTR and a trend to increase in WBPS were observed. El-Kadi et al. (2006) also found that MP intake, increased from 75 to $180 \mathrm{~g} /$ day by intraduodenal infusion of casein, enhanced whole body appearance and net absorption of Leu.

Plasma valine, glutamic acid and urea concentrations increased $(P<0.05)$ with increasing MP intake, but plasma ammonia concentrations remained unchanged. Raggio et al. (2004) studied the effect of MP supply (1922-2517 g/day) on splanchnic flux of amino acids in lactating cows and found that ammonia absorption and hepatic ureagenesis increased but urea recycling decreased with increasing MP supply, resulting in unchanged plasma ammonia concentration and increased plasma urea concentration. Similar changes would occur in the present experiment. Raggio et al. (2004) also observed that, in lactating cows, milk production and arterial plasma concentrations of isoleucine, Leu, lysine and valine essential amino acids increased with increasing MP supply, whereas the ratio of the essential amino acids in milk protein relative to portal absorption showed trends to reduce. Because the MP requirement in lactating cows is considerably greater than for growing heifers (AFRC 1993), nutritional and physiological status may be involved in the different trends of plasma amino acid concentrations. The nonsignificant changes in plasma insulin concentrations with increased MP intake accorded with the result of sheep (Sano et al. 2004). In this regard, Sano \& Terashima (2001) reported that in sheep, tissue responsiveness and sensitivity to insulin tended to be enhanced with increased dietary CP intake. Tesseraud et al. (1993) studied the effect of insulin infusion on Leu metabolism under euglycaemic and eukalemic clamps in lactating and dry goats, and reported that insulin accelerated net Leu balance mainly due to reduced protein degradation even though total Leu flux and non-oxidative Leu disposal was unchanged. Therefore, it may be possible that insulin has less influence on WBPS.

Heat production was comparable with those reported in calves and growing steers (Lobley et al. 1987; Chwalibog et al. 1996; Derno et al. 2005) and was little influenced by MP intake of isoenergetic diets in the present experiment. The higher (but not significant) respiratory quotient for the Hi-MP diet might partly be related to protein oxidation, even though the contribution as energy source was limited 
(Lobley et al. 1980). Lapierre et al. (1999) reported that in growing beef steers, FLeuOX increased with increasing intake level $(9,17$ and $20 \%$ for low, medium and high intake, respectively). Lapierre et al. (2002) determined the effect of the supply of MP on whole body Leu kinetics and WBPS in late-lactation dairy cows, and reported that FLeuOX was 21.2 and $16.0 \%$ for the high and middle MP supply, respectively. In the present experiment, FLeuOX was similar to those reported previously but did not increase significantly with increased MP intake. This may partly be a consequence of the small differences in MP intake between diets. It seemed likely that, in lactating cows, more amino acids were utilized as an energy source with increased MP supply (Lapierre et al. 2002).

In the present experiment, LeuOX was divided into LeuOXpl and LeuOXin as reported by Wolfe et al. (1982) and Goodenough et al. (1982) who determined LeuOXpl and LeuOXin separately during exercise and cold exposure, respectively, using both enrichments of plasma $\left[1-{ }^{13} \mathrm{C}\right]$ Leu and $\alpha-\left[1-{ }^{13} \mathrm{C}\right] \mathrm{KIC}$ in humans. Exercise enhanced LeuOX, LeuOXpl and LeuOXin, whereas cold exposure enhanced LeuOX and LeuOXpl but not LeuOXin. The ratio of LeuOXin to LeuOX in heifers was comparable with that reported in humans (Goodenough et al. 1982; Wolfe et al. $1982)$ and LeuOXin increased $(P=0.044)$ with increased MP intake, whereas LeuOX and LeuOXpl increased only numerically. These results suggest that the component of LeuOX that occurs in the cell of origin from protein catabolism was enhanced with increased MP intake.

It is suggested that, in heifers, plasma LeuTR and WBPS are influenced by MP intake, even when the increase in MP is relatively modest and ME intake is constant.

This study was in part supported by the Japan Livestock Technology Association. The authors are grateful to $\mathrm{K}$. Taylor for his kind comments on this paper.

\section{REFERENCES}

AFRC (1993). Energy and Protein Requirements of Ruminants. An Advisory Manual Prepared by the AFRC Technical Committee on Responses to Nutrients. Wallingford, UK: CAB International.

Allsop, J. R., Wolfe, R. R. \& Burke, J. F. (1978). Tracer priming the bicarbonate pool. Journal of Applied Physiology 45, 137-139.

Anthony, J. C., Yoshizawa, F., Anthony, T. G., Vary, T. C., Jefferson, L. S. \& Kimball, S. R. (2000). Leucine stimulates translation initiation in skeletal muscle of postabsorptive rats via a rapamycin-sensitive pathway. Journal of Nutrition 130, 2413-2419.

Brouwer, E. (1965). Report on sub-committee on constants and factors. In Energy Metabolism (Ed. K. L. Blaxter), pp. 302-304. London: Academic Press.

Calder, A. G. \& Smith, A. (1988). Stable isotope ratio analysis of leucine and ketoisocaproic acid in blood plasma by gas chromatography/mass spectrometry. Use of tertiary butyldimethylsilyl derivatives. Rapid Communications in Mass Spectrometry 2, 14-16.

Chwalibog, A., Jensen, K. \& Thorbek, G. (1996). Oxidation of nutrients in bull calves treated with beta adrenergic agonists. Archives of Animal Nutrition 49, 255-261.

Cobelli, C., Saccomani, M. P. \& Tessari, P. (1991). Compartmental model of leucine kinetics in humans. American Journal of Physiology 261, E539-E550.

Dawson, J. M., Greathead, H. M. R., Craigon, J., Hachey, D. L., Reeds, P. J., Pell, J. M. \& Buttery, P. J. (1998). The interaction between nutritional status and growth hormone in young cattle: differential responsiveness of fat and protein metabolism. British Journal of Nutrition 79, 275-286.

Derno, M., Jentsch, W., Schweigel, M., Kuhla, S., Metges, C. C. \& Matthes, H.-D. (2005). Measurements of heat production for estimation of maintenance energy requirements of Hereford steers. Journal of Animal Science 83, 2590-2597.

El-Kadi, S. W., Baldwin, R. L., VI, Sunny, N. E., Owens, S. L. \& Bequette, B. J. (2006). Intestinal protein supply alters amino acid, but not glucose, metabolism by the sheep gastrointestinal tract. Journal of Nutrition 136, 1261-1269.

Fujita, T., Kajtta, M. \& Sano, H. (2006). Responses of whole body protein synthesis, nitrogen retention and glucose kinetics to supplemental starch in goats Comparative Biochemistry and Physiology 144, 180-187.

Goodenough, R. D., Royle, G. T., Nadel, E. R., Wolfe, M. H. \& Wolfe, R. R. (1982). Leucine and urea metabolism in acute human cold exposure. Journal of Applied Physiology 53, 367-372.

Hammond, A. C., Huntington, G. B., Reynolds, P. J., Tyrrell, H. F. \& Eisemann, J. H. (1987). Absorption, plasma flux and oxidation of L-leucine in heifers at two levels of intake. Journal of Animal Science 64, 420-425.

Krishnamurti, C. R. \& Janssens, S. M. (1988). Determination of leucine metabolism and protein turnover in sheep, using gas-liquid chromatography-mass spectrometry. British Journal of Nutrition 59, 155-164.

Lapierre, H., Bernier, J. F., Dubreuil, P., Reynolds, C. K., Farmer, C., Ouellet, D. R. \& Lobley, G. E. (1999). The effect of intake on protein metabolism across splanchnic tissues in growing beef steers. British Journal of Nutrition 81, 457-466.

Lapierre, H., Blouin, J. P., Bernier, J. F., Reynolds, C. K., Dubreuil, P. \& Lobley, G. E. (2002). Effect of supply of metabolizable protein on whole body and splanchnic leucine metabolism in lactating cows. Journal of Dairy Science 85, 2631-2641.

Lobley, G. E., Connell, A. \& Buchan, V. (1987). Effect of food intake on protein and energy metabolism in finishing beef steers. British Journal of Nutrition 57, 457-465. 
Lobley, G. E., Milne, V., Lovie, J. M., Reeds, P. T. \& Pennie, K. (1980). Whole body and tissue protein synthesis in cattle. British Journal of Nutrition 43, 491-502.

Lobley, G. E. (1992). Control of the metabolic fate of amino acids in ruminants: a review. Journal of Animal Science 70, 3264-3275.

Matthews, D. E., Motil, K. J., Rohrbaugh, D. K., Burke, J. F., Young, V. R. \& Bier, D. M. (1980). Measurement of leucine metabolism in man from a primed, continuous infusion of L-[1- $\left.{ }^{13} \mathrm{C}\right]$ leucine. American Journal of Physiology 238, E473-E479.

Nolan, J. V. (1993). Nitrogen kinetics. In Quantitative Aspects of Ruminant Digestion and Metabolism (Eds J. M. Forbes \& J. France), pp. 123-143. Wallingford, UK: CAB International.

Obara, Y., Fuse, H., Terada, F., Shibata, M., Kawabata, A., Sutoh, M., Hodate, K. \& Matsumoto, M. (1994). Influence of sucrose supplementation on nitrogen kinetics and energy metabolism in sheep fed with lucerne hay cubes. Journal of Agricultural Science, Cambridge 123, 121-127.

Raggio, G., Pacheco, D., Berthiaume, R., Lobley, G. E., Pellerin, D., Allard, G., Dubreuil, P. \& Lapierre, H. (2004). Effect of level of metabolizable protein on splanchnic flux of amino acids in lactating dairy cows. Journal of Dairy Science 87, 3461-3472.

Rocchiccioli, F., Leroux, J. P. \& CARTier, P. (1981). Quantitation of 2-ketoacids in biological fluids by gas chromatography chemical ionization mass spectrometry of $o$-trimethylsilyl-quinoxalinol derivatives. Biomedical Mass Spectrometry 8, 160-164.

Sano, H., Kajita, M. \& Fujita, T. (2004). Effect of dietary protein intake on plasma leucine flux, protein synthesis, and degradation in sheep. Comparative Biochemistry and Physiology B139, 163-168.

Sano, H. \& Terashima, Y. (2001). Effects of dietary protein level and cold exposure on tissue responsiveness and sensitivity to insulin in sheep. Journal of Animal Physiology and Animal Nutrition 85, 349-355.

SAS (1996). SAS/STAT ${ }^{\mathbb{B}}$ Software: Changes and Enhancements through Release 6.11. Cary, NC, USA: SAS Institute Inc.

Tessari, P., Tsalikian, E., Schwenk, W. F., Nissen, S. L. \& HAYMOND, M. W. (1985). Effects of $\left[{ }^{15} \mathrm{~N}\right]$ leucine infused at low rates on leucine metabolism in humans. American Journal of Physiology 249, E121-E130.

Tesseraud, S., Grizard, J., Debras, E., Papet, I., Bonnet, Y., Bayle, G. \& Champredon, C. (1993). Leucine metabolism in lactating and dry goats: effect of insulin and substrate availability. American Journal of Physiology 265, E402-E413.

Wolfe, R. R., Goodenough, R. D., Wolfe, M. H., Royle, G. T. \& NADEL, E. R. (1982). Isotopic analysis of leucine and urea metabolism in exercising humans. Journal of Applied Physiology 52, 458-466.

Young, B. A., Kerrigan, B. \& Christopherson, R. J. (1975). A versatile respiratory pattern analyzer for studies of energy metabolism of livestock. Canadian Journal of Animal Science 55, 17-22. 